Article

\title{
Success Criteria Evaluation for a Sustainable and Affordable Housing Model: A Case for Improving Household Welfare in Nigeria Cities
}

\author{
Aliyu Ibrahim Saidu and Chunho Yeom * \\ International School of Urban Sciences, University of Seoul, Seoul 02504, Korea; asaidu26@gmail.com \\ * Correspondence: chunhoy7@uos.ac.kr; Tel.: +82-2-6490-5154
}

Received: 21 November 2019; Accepted: 12 January 2020; Published: 16 January 2020

\begin{abstract}
Due to rapid urbanization and the recent growing influx of migrants from politically fragile states, cities are now faced with an impending housing problem. In developing countries like Nigeria, the impacts of the housing problem, which include economic, social (humanitarian), and environmental crises, are evident. Recently, sustainability has become a central theme for public discussion, not only in expanding housing for the growing population but also in improving the quality of residential livelihoods of low-income households without compromising the housing needs of future generations. So far, there have been numerous studies conducted on sustainable housing in Nigeria, touching on sustainability in housing but mostly from the professionals' point of view. Therefore, a document content analysis to generate success criteria and a survey for household validation were conducted. Results show that security ranks the highest, and other criteria of importance include accessibility, adaptability, utility, technology, community, affordability, and acceptability. Hence, the study concludes that social and environmental sustainability in housing should enhance household satisfaction by ensuring the security and welfare of its residents, adapt to its immediate environment, be acceptable, be supported with social amenity to integrate the community through participation, and, finally, manage household utility efficiently.
\end{abstract}

Keywords: sustainability; sustainable housing; affordable housing; success criteria; household

\section{Introduction}

There is a global problem of housing the poor. It has been estimated that there is an annual population increase of approximately 83 million people in the world; hence, there will be roughly a total population of 8.9 billion by the year 2050 [1]. A study conducted in Europe shows that people find it difficult to afford to buy a house. Normally, the cost of housing in urban areas often outweighs household income. Additionally, housing assets are a source of wealth, and has impact on spatial inequality, and could be a potential determinant to intergenerational discrimination within a society [2]. Sustainable and affordable housing is a hot button topic for researchers from both developed and developing countries. It has been realized that housing for the poor and low-income earners should be paramount to the academic and policymaker [3]. Less developed countries are putting much effort into ending housing problems due to their growing populations [4].

The policies on housing, in the case of Nigeria, was first initiated and developed by their British colonial masters. The policies were formulated as an adaptation of British housing policies and were not only separationist in nature but also not sustainable. Many attempts have been made by the government to elicit and initiate national housing policies since the country's independence. Unfortunately, the problem of housing persists, and it is on the rise [5]. Housing projects have been executed in significant towns and cities in Nigeria, but are inadequate to meet the demand for housing. 
With a population of over 180 million, the Nigerian government needs to formulate workable policies and housing programs to provide decent housing for the growing masses. By 2020, there will be a housing deficit between 17 to 20 million housing stock. The housing problem in Nigeria can be described from both the supply and the demand perspectives. Although the government has invested enormous capital on expanding housing supply through National Housing Programmes, it has yielded little or no result on housing supply.

According to the background, which describes the housing situation, the authors find that current housing stock is not in the best living conditions for human habitation. Thus, it is not only inadequate but also deteriorating and overcrowded. Meanwhile, the National Housing Programmes in place lack continuity and consistency and are impacted by political interference and nepotism [5-7]. There is a proliferation of slum populations in town and cities in Nigeria because it is difficult for the general masses to afford or rent decent housing (Tables 1 and 2). The average income of a civil servant is grossly inadequate due to the enormous disparities in income. As of 2018, the least paid individual (national minimum wage) in a month is N18,000 (USD 50), and the average monthly wage is about N43,200 (USD 120) [8,9]

Table 1. List of housing prices in Abuja City (source: Federal Housing Authority).

\begin{tabular}{ccc}
\hline Housing Type & Unit Price (N) & Unit Price (USD) \\
\hline 2 bedroom block of flat & $22,500,000$ & 62,500 \\
3 bedroom block of flat & $35,500,000$ & 98,611 \\
4 bedroom terrace duplex & $65,500,000$ & 181,944 \\
4 bedroom semi-detached duplex & $70,500,000$ & 195,833 \\
4 bedroom detached duplex & $99,500,000$ & 276,389 \\
5 bedroom semi-detached triplex & $90,500,000$ & 251,389 \\
5 bedroom detached duplex & $120,000,000$ & 333,333 \\
\hline
\end{tabular}

Table 2. List of housing rental fees in Abuja City (source: https://www.numbeo.com/cost-of-living/).

\begin{tabular}{cc}
\hline Rent Per Month in Abuja & Price (USD) \\
\hline Apartment (1 bedroom) in city centre & 1328 \\
Apartment (1 bedroom) outside of centre & 518 \\
Apartment (3 bedrooms) in city centre & 3439 \\
Apartment (3 bedrooms) outside of centre & 1875 \\
\hline
\end{tabular}

It is gainsaying that housing policies and programs initiated by the government do not employ sustainable strategies that are realistic, affordable, and acceptable by end-users. It is also not unusual to find empty and abandoned houses in the city center. Hence, the government has not only worsen the housing crisis but also failed to satisfy the desired housing needs sustainably over time $[10,11]$. A study by Ibem and Azuh supported the fact that weak sociopolitical structure and institutional frameworks are the banes of failed housing policies and its implementation mechanisms [12]. Additionally, corruption is a huge stumbling block in housing delivery and procurement processes [13]. More so, Thua et al. associated poor housing quality and housing management services, which eventually result in time and cost overruns, with bad estate and project management practices [14]. Furthermore, Adekunle et al. described, with sharp empirical pieces of evidence, the connection between respiratory-related diseases in children and the quality of air in a house [15].

The study aims to establish a process of assessing success criteria to achieve a sustainable housing model from the household viewpoint. To achieve this aim, the objectives of the study are to evaluate economic, social, and environmental success criteria from the end-users' perspective, and to validate and rank the evaluated success criteria as presented in Figure 1. The city of Abuja, the administrative capital of Nigeria, was chosen as the study area. Furthermore, it is a model city with a defined master plan, having several public and private housing estates (pilot housing schemes and programs) that 
are usually scaled up and duplicated across the nation. It is centrally located geographically, making it a melting pot for different groups of people with varying socio-economic and religious-cultural backgrounds living together. Furthermore, the survey of the study will be validated by surveying respondents from heads of households who are government employees.

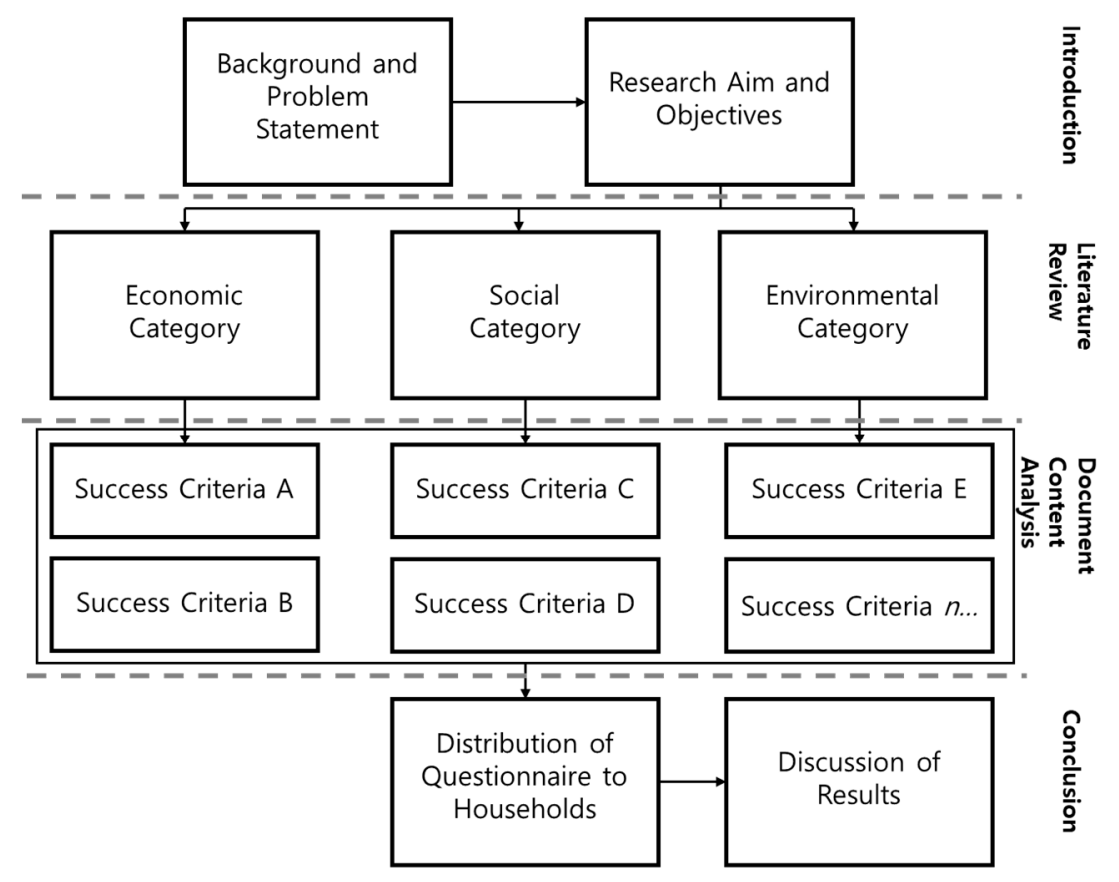

Figure 1. Conceptual framework of the study.

It has been recorded that one half of the world's population are residents in urban centers, and it was further predicted that it would increase two-fold by the year 2030, which will lead to increased human activity. However, this increased urban activity will exacerbate the greenhouse gas effect of the earth's atmosphere, thereby leading to increased heating of the earth, known as global warming. Furthermore, it was projected that by 2030 , OECD countries would need an $80 \%$ share of global energy in their cities to meet its energy demand for economic growth. Consequently, we can see that not only the cities significantly contribute to the problems of climate, but also will be negatively impacted by its effects, socially and environmentally.

Climate change not only impacts the urban area economically but also impacts the fabric of the city's social structure. When impacts of climate change disrupt livelihoods, it leads to displacement of the populace and then poverty. Also, social vices such as crimes and civil conflicts will be widespread; hence, people will no longer feel safe. More so, these social calamities usually cause a health issue that has to do with mental instability. Likewise, skin diseases could be derived from exposure to heatwaves as a result of the heat island effect. Thirdly, buildings are generally vulnerable environmentally from the impacts of climate change due to factors of vulnerability, from the volume of impact to its level of exposure. Mostly, urban areas are located in coastal regions and the riversides, which make them vulnerable to the impacts of climate change. Some of the environmental impacts include urban flooding, a rise in the sea level in coastal cities, heat waves due to the heat island effect, hurricanes, and typhoons [16]. Empirical pieces of evidence have proven that buildings contribute immensely in exacerbating the effects of global warming. Therefore, in accordance to the United Nations Climate Change conferences and the Kyoto agreement, member countries have signed a resolution to act accordingly with combined efforts and objectives to tradeoff between cutting down or reducing the emissions of greenhouse gasses into the atmosphere by adopting sustainable means of development [17]. 
Against this backdrop, the United Nations Sustainable Development Goals (SDG) resolved to tackle global urban problems such as reducing poverty, enhancing good health, available and affordable renewable energy, sustainable cities and communities, climate change, and finally, building strong institutions. Thus, this resolution has given governments, particularly of the less developed countries, the thrust to pursue all avenues to meet these goals. The study, therefore, provides a significant contribution to research in developing a multiple success criteria model for achieving sustainable and affordable housing [18].

There is no universally accepted definition of sustainable and affordable housing. There have been many attempts to define it by several authors and researchers from deferent fields and disciplines. It is also important to note that empirical studies have shown that professionals and academics in the housing sector differ in opinion on what constitutes success criteria for achieving sustainable and affordable housing. A framework of success criteria is limited but highly significant, and the approach of its development is drawn from inputs from different professionals of different disciplines [19].

To describe and distinguish between the concepts of sustainability and affordability in housing, first, some definitions of sustainable and affordable housing will be highlighted as proposed by researchers. Research by Adabre and Chan attempted to define sustainable and affordable housing by trying to link sustainability and affordability in housing as a means of enhancing household and stakeholder satisfaction, by reducing housing operation cost, the time factor, affordability and quality of housing [20]. In another study, sustainable, affordable housing is the development and maintenance of housing, to support and satisfy general human needs, and preserve the environment now and for the future. The housing should be qualitative, marketable, and affordable throughout its life cycle [21].

The UN habitat describes sustainable and affordable housing from the policy perspective as "sustainability housing development (along the four dimensions of sustainability-environmental, social, cultural and economic) that impacts the environment and climate change, durability and resilience of homes, economic activities in housing and their links with the wider economy, cultural and social fabric of communities, and ... poverty alleviation, social development, and quality of life." [22].

Furthermore, Ibem and Azuh proposed a definition that sustainable and affordable housing "... is the adoption of a housing and neighborhood environment, housing quality, affordability, quality of life, maintaining cultural heritage and technical feasibility" [12]. On the contrary, Jiboye argued that sustainable and affordable housing is the optimal utilization of limited resources to provide housing for the masses as well as for future generations [8-12]. Also, Mitlin and Satterthwaite propounded that sustainable and affordable housing is improving the health and safety of residence; it should be affordable, secure, water and energy-efficient, connected to infrastructure, social amenities, resilient to natural and human-made disasters, and lastly, meeting the people's needs and choices. Thus, it should be functional, durable, and employ sustainable and affordable housing designs to optimize the use of utility throughout its life cycle [23].

According to the 1987 World Commission on Environment and Development, the Brundtland Commission report, the most famous definition of sustainability is the development that meets the needs of the present generation within the available scarce resources and carrying capacity of the environment without endangering the needs and carrying capacity of future generations. Hence, sustainable and affordable housing is housing that manages and coexists within the limitations of available scarce resources, at the same time preserving and conserving these resources for future needs.

However, there is less reliable research conducted within the Nigerian context involving the contribution of the low-income household, which constitutes the demand side of the housing market, as part of the decision-makers in evaluating and validating sustainable and affordable housing success criteria. Therefore, the motivation for this study is to fill that gap and to enhance the decision-making process for policymakers to achieve sustainable and affordable housing for low-income households in Nigeria. 


\section{Materials and Methods}

A document content analysis was undertaken, and a structured, close-ended questionnaire, as presented in Appendix A, was distributed in the course of the study. A qualitative analysis to retrieve secondary data from extant literature must contain sustainability criteria, factors, and constituents in housing [24]. Therefore, success criteria that are profound, distinctly described, and frequently put forward by the documents were generated. Hence, 17 success criteria were generated, as shown in Figures 2 and 3 , and further collapsed to 8 distinct success criteria by combining closely related criteria, which were used as variables to be analyzed (Table 3).

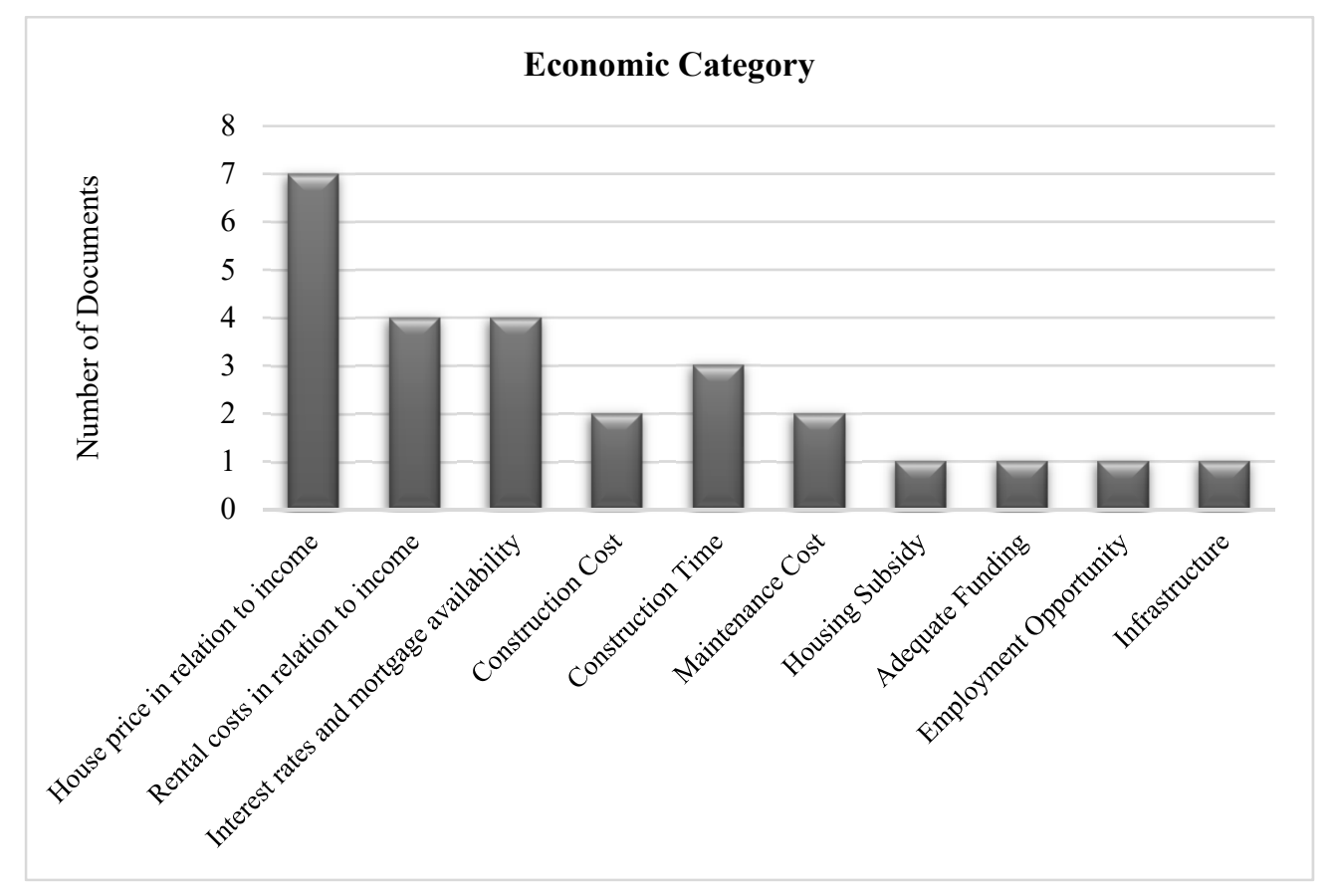

Figure 2. Economic success criteria generated from document content analysis.

Data collected was evaluated by expressing the feelings and opinions of success criteria within a scale of 1 (very weak) to 5 (very strong). The sample group comprised of civil servants working in Abuja. This sample group has expressly indicated their need for housing from their monthly contribution of a percentage of their earnings into the National Housing Fund. The questionnaire survey utilized a Google online form to collate data from the demand side via emails, online links, and other social media outlets. The National Bureau of Statistics reported the population size of federal civil servants employed by the government as 67,000 workers. The sampled population size needed for the study is 262 , determined under a confidence level of $95 \%$ and at a confidence interval of 6.04 . Only 51 respondents engaged in the survey, which is $19 \%$ of the sampled population. According to Blaike, it is factual that most research work seldom achieves a whole or a part sampling group or unit [25]. There are other scholarly opinions about the rate of response, which ranges between $10 \%$ to $95 \%$. For example, Akintoye and Fitzgerald suggested that for a research survey that involves personal contacts, the response rate is $95 \%$, and for responses via mail, it is between $20 \%$ to $40 \%$ [26]. However, the Survey gizmo suggested that response rates from electronic mails (emails and other social media platforms) regarding surveys on public opinion are between $10 \%$ to $15 \%$ [27].

The respondents were made to evaluate the multiple success criteria based on their feelings and perspectives as to the level of importance of eight success criteria, namely, affordability in housing, accessibility of housing, technology in housing, acceptability in housing, community participation in housing, security in housing, adaptability in housing development, utility in housing development. 

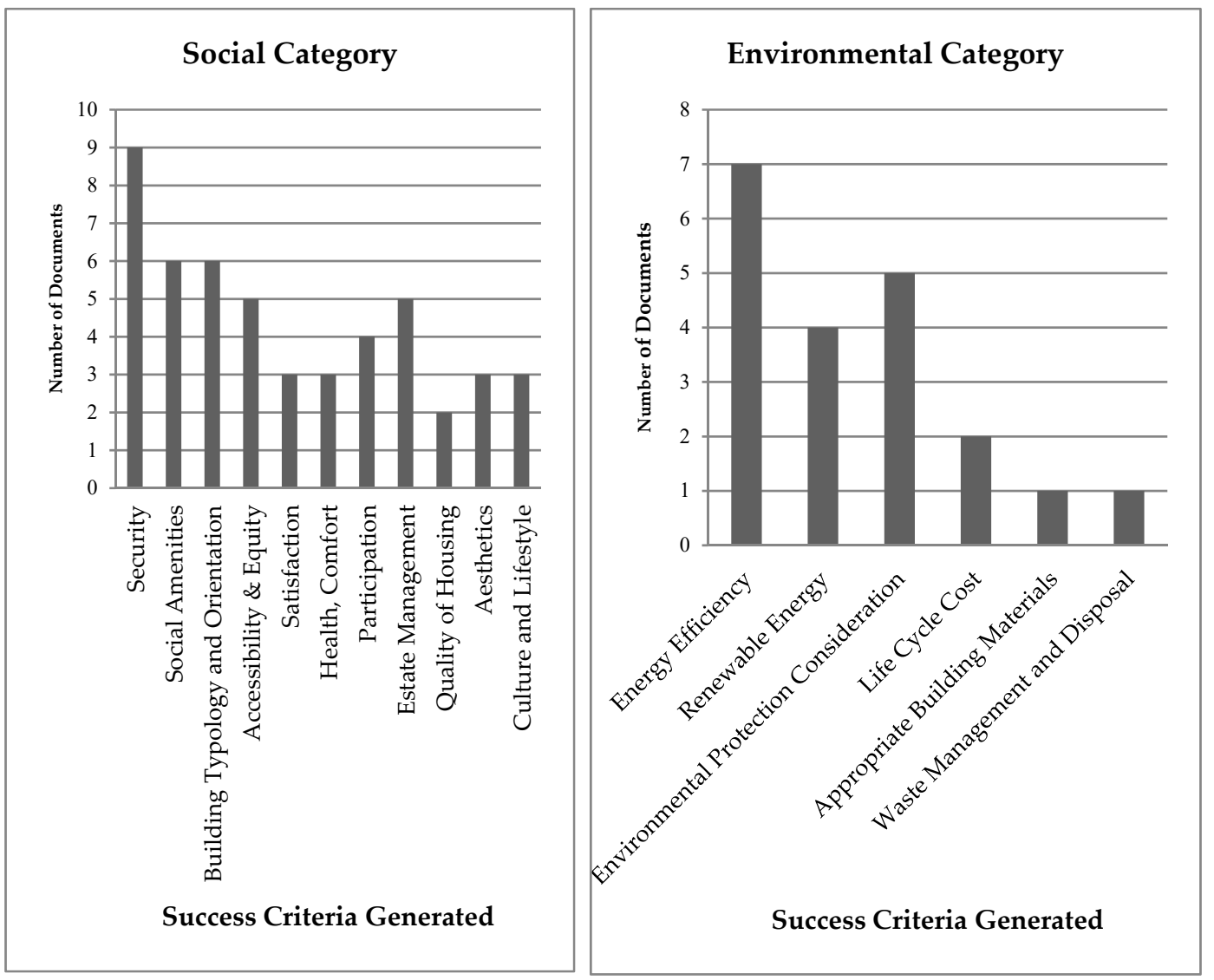

Figure 3. Social and environmental success criteria generated from document content analysis.

Table 3. Process of combining related criteria into single success criteria.

\begin{tabular}{cc}
\hline Combination of Related Criteria & Codified Criteria \\
\hline $\begin{array}{c}\text { House price concerning income } \\
\text { Rental costs concerning income } \\
\text { Interest rates and mortgage availability } \\
\text { Housing subsidy } \\
\text { Adequate funding }\end{array}$ & Affordability \\
\hline Employment opportunity & \\
Infrastructure & Accessibility \\
\hline Reducing construction cost & Technology application \\
Reducing construction time & \\
Reducing maintenance cost & Acceptability \\
Culture and lifestyle & \\
Building typology and orientation & \\
Aesthetics & Community \\
Satisfaction & Equity \\
Participation & Security \\
Social amenities & \\
Estate management & \\
Security & \\
Quality of housing & \\
\hline
\end{tabular}


Table 3. Cont.

\begin{tabular}{cc}
\hline Combination of Related Criteria & Codified Criteria \\
\hline Energy efficiency & Utility \\
Renewable energy & \\
Life cycle cost & \\
\hline Appropriate building materials & Adaptability \\
Waste management and disposal & \\
Environmental protection consideration & \\
\hline
\end{tabular}

Analysis of data acquired was conducted using the Microsoft Excel data analysis tool for measurements of central tendencies, correlation, and ANOVA. Therefore, it is essential to do a reliability test for the data collected to prove the validity and significance of the result derived from the study. Therefore, ANOVA was utilized to get the significant $F$ and $p$-value; thus, data less than 0.05 has a significant difference from other paired variables. Therefore, the correlation analysis in Table 4 shows the $r$-value, sometimes known as the Pearson correlation coefficient, indicating the strength of the criteria to each other. The output of the correlation analysis shows that Adaptability and Utility have the strongest means of association with each other, with the coefficient $r$-value of 0.82 . The second in the strength of the association is the criteria Community and Utility. Additionally, Table 5 shows that ten paired success criteria that are statistically significant and reliable with a significant $F$ and $p$-value less than 0.05 . It shows that the data collected is valid, unbiased, and has statistical significance.

Table 4. Correlation matrix table.

\begin{tabular}{ccccccccc}
\hline & Affr. & Acces. & Tech. & Accep. & Comm. & Secr. & Adap. & Util. \\
\hline Affr. & 1.000 & & & & & & & \\
Acces. & 0.721 & 1.000 & & & & & & \\
Tech. & 0.591 & 0.525 & 1.000 & & & & & \\
Accep. & 0.459 & 0.597 & 0.664 & 1.000 & & & \\
Comm. & 0.473 & 0.371 & 0.687 & 0.474 & 1.000 & & & \\
Secr. & 0.423 & 0.549 & 0.669 & 0.528 & 0.622 & 1.000 & & \\
Adap. & 0.439 & 0.324 & 0.596 & 0.416 & 0.672 & 0.567 & 1.000 & 1.000 \\
Util. & 0.600 & 0.549 & 0.678 & 0.503 & 0.718 & 0.642 & 0.816 & \\
\hline
\end{tabular}

Table 5. Reliability table; $p=p$-Value, and $F=$ significant $\mathrm{F}$.

\begin{tabular}{|c|c|c|c|c|}
\hline & Acceptability & Adaptability & Community & Security \\
\hline \multicolumn{5}{|c|}{ Adaptability } \\
\hline$p$ & - & & & \\
\hline$F$ & 0.00237 & & & \\
\hline \multicolumn{5}{|c|}{ Community } \\
\hline$p$ & - & 0.00356 & & \\
\hline$F$ & 0.0005 & - & & \\
\hline \multicolumn{5}{|c|}{ Security } \\
\hline$p$ & 0.00253 & 7.8 & 0.51 & \\
\hline$F$ & - & - & - & \\
\hline \multicolumn{5}{|c|}{ Utility } \\
\hline$p$ & - & 0.005 & 0.0315 & 0.848 \\
\hline$F$ & 0.00017 & - & - & - \\
\hline
\end{tabular}




\section{Results}

The average monthly income of respondents is USD 369. Results indicate that $59 \%$ of the 50 respondents claim that they do not own houses, and it was also found that $77.4 \%$ of homeowners claim that they privately built their houses, through self-help, without any government intervention or assistance.

Table 6 indicates the profile of respondents who are government officials, from junior officers who are from grade level 04 to 07 , senior officers who are from grade level 08 to 09 , and then the directorate level who are at grade level 10 to 15 . We find a considerable margin of about USD 1035 between senior officers at grade level 09 and officers at the directorate level. It clearly shows that senior officers who are in the majority are unable to buy or rent decent housing in the central city of Abuja.

Table 6. Respondents (household) profiles.

\begin{tabular}{|c|c|c|c|c|c|c|}
\hline Position & Grade & Education & $\begin{array}{c}\text { Monthly } \\
\text { Salary USD }\end{array}$ & $\begin{array}{c}\text { Male } \\
\text { Respondents }\end{array}$ & $\begin{array}{c}\text { Female } \\
\text { Respondents }\end{array}$ & Total \\
\hline Junior officer & Level 04 & Secondary school & 56 & 0 & 1 & 1 \\
\hline Junior officer & Level 07 & Diploma & 120 & 2 & 1 & 3 \\
\hline Senior officer & Level 08 & University graduate & 181 & 16 & 5 & 21 \\
\hline Senior officer & Level 09 & University graduate & 227 & 24 & - & 24 \\
\hline \multirow[t]{2}{*}{ Director } & Level 15 & University graduate & 1262 & 2 & - & 2 \\
\hline & Total & & & 44 & 7 & 51 \\
\hline
\end{tabular}

The description in Table 7 shows success criteria Security is having an average means of 0.85 (highest). Interestingly, Affordability has a means of 0.75 falling short behind Community and Utility, which are both having a means of 0.77 . The success criteria Security and Adaptability both have a standard deviation of 0.179 and 0.178 , respectively. The variances from the central means of criteria Acceptability and Security are 0.0317 and 0.0321 , respectively.

Table 7. Means, standard deviation, and variance.

\begin{tabular}{cccc}
\hline Criteria & Mean & SD & $\mathbf{S}^{2}$ \\
\hline Affordability & 0.752941176 & 0.235247 & 0.055341176 \\
Accessibility & 0.823529412 & 0.214092 & 0.045835294 \\
Technology & 0.77254902 & 0.226343 & 0.051231373 \\
Acceptability & 0.784313725 & 0.178183 & 0.03174902 \\
Community & 0.768627451 & 0.231076 & 0.053396078 \\
Security & 0.854901961 & 0.179236 & 0.03212549 \\
Adaptability & 0.788235294 & 0.234646 & 0.055058824 \\
Utility & 0.768627451 & 0.244532 & 0.059796078 \\
\hline
\end{tabular}

The success criteria that are most scored, as indicated in Figure 4, is Security, followed by Accessibility with average scores of 27 and 25, respectively. The lowest scored are Affordability and Acceptability, both having average scores of 18 and 15, respectively. It is evident, in this case, that the respondents view and score security most highly, compared to other criteria. 


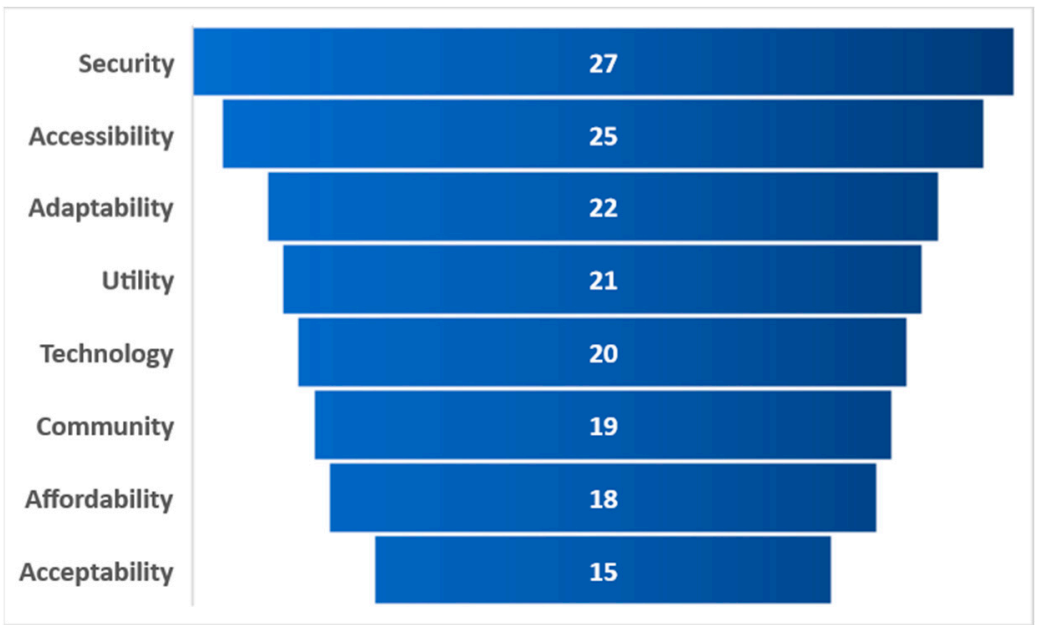

Figure 4. Chart showing the scores of success criteria from household responses.

\section{Discussion}

Ongoing studies on sustainable and affordable housing deal with numerous criteria and factors, which touch on the three sustainability pillars, i.e., economic, social, and environmental. However, most of these works have not been put to practice, and the Nigerian government continues to invest heavily in housing without result [28]. The academic world has emphasized the need for sustainable and affordable housing; however, we find a disconnect and complete lack of collaboration between stakeholders in the housing sector [29]. A success criteria model for sustainable and affordable housing is not only envisaged or visible in developed economies but also emerging economies. In this milieu of growing population and lean resources from the oil-rich economy of Nigeria, several research papers have been published on sustainable and affordable housing as a panacea to this impending urban challenge the country is faced with. Therefore, based on the results of the study, we can deduce some conclusions to improve the social and environmental sustainability in housing to enhance household satisfaction.

\subsection{Security and Welfare in Housing}

The study illustrates that security in housing developments is of optimum importance as a priority to satisfy homeowners, ensuring comfort by providing effective estate or facility management practice to maintain the quality and value of housing assets. Furthermore, housing provision must ensure the security of lives and property of the end-users. Sub-criteria includes comfort; buildings should achieve physical and psychological comfort. Effective facility management should be in place to maintain the value of the buildings. The quality of buildings should be considered as an asset to attract investment. Safety and security of lives and property should be paramount, and the privacy of households should be maintained. Furthermore, Xiaosen H. and Ayedun both agree that improving the health and wellbeing of low-income households can be achieved by the government investing in improving the physical and structural quality of housing stock. Structural components such as the size and nature of windows to improve cross ventilation within a living area, refurbishments of ceilings, walls, and floor improvements are significant in improving residential health and livelihoods of low-income households [30,31].

\subsection{Accessibility of Housing}

Accessibility in housing development is the provision of quality and serviceable transportation infrastructure (i.e., bus services, road networks, cycling tracks, and pedestrian sidewalks) in housing projects. It allows easy and quick access to and from a place of employment and job opportunities. Sub-criteria includes a quality transportation system, quality road infrastructure, proximity to a job, 
and employment opportunity. Thus, the movement of people between their homes and employment is enhanced.

\subsection{Adaptability in Housing}

Adaptability in housing is enforcing environmental protection standards to control air, water, and noise pollution, during and after the construction of housing projects, reducing, reusing, and recycling construction material waste, and also using locally available building materials. Sub-criteria includes that environmental protection in building projects should adhere to environmental standards, codes, and regulations to mitigate air and water pollution. Solid and effluent waste should be properly managed for the health of the household. Xiaosen $\mathrm{H}$. has said that construction waste materials should be reduced, reused, and recycled. Indigenous and local building materials should be patronized and made available to protect the environment [30]. It has been suggested by a recent study that education and awareness are driving tools in achieving sustainability in housing development. Traditional or informal systems of education, as proposed by Ayedun et al. and Muhamad et al., should be introduced into the school curriculum by the government.

Morals, and ethical values embedded in them, will positively impact man's attitude towards his fellow humans. It will also imbibe respect and reverence towards land and the entire ecosystem [31,32]. Moreover, land use and acquisition are significant factors when confronting housing in general. Also, it is the base and foundation for the survival of the ecosystem. Hence, the land is strongly considered from the three dimensions of sustainability, according to Gbadegesin, J.T [33]. The construction industry has a responsible role to play in protecting the environment, considering that it has contributed negatively to environmental degradation. Thus, it is incumbent that the construction industry treads a path that promotes environmental protection standards. Therefore, geographical locations with a high degree of utility should be priorities for achieving sustainability, Rosli, S. et al. have said [34].

Meanwhile, the price and scarcity of land, according to Omar S., have a direct effect on the cost of housing [35]. Also, Arnab, J. et al. said in their study that the provision of land is one of the most critical components in actualizing sustainable and affordable housing. Policy measures dealing with land will create an enabling environment for sustainable housing projects. Some of these land policies include land price, land acquisition, and compensation procedure, land titling and documentation, land use planning, and mixed land use [3].

\subsection{Utility in Housing}

Utility in housing provision is promoting and ensuring efficient use of energy and water in the building by the use of alternative and renewable sources of generating energy and installation of electrical and plumbing controls to reduce the life cycle cost of buildings. The study result outcome shows that efficient use of energy and water in buildings is the optimum criterion to reduce the life cycle cost of the building, improving residential livelihood and increasing housing utilities, as supported by Afolabi [36]. However, according to the results gathered, we find utility ranked as least important. It is also interesting to note that utility has a solid correlation with both adaptability and community, as indicated in Table 5. The importance of efficient use and management of utilities such as energy and water cannot be understated, buttressed with the fact that Carolyn S. [37] agrees in her study that sustainability is driven by utility, while Kamand M. et al. [38] agrees with her position. Furthermore, Li Cheng et al. [39] emphasized that energy efficiency should be considered at the early design stages of a housing project, while energy rating systems should be established and adhered to, as suggested by Hector S. et al. [40]. However, Mohammad K. suggested that the modular system of construction will optimize the energy performance of buildings, hence reducing life cycle cost [41].

\subsection{Building Technology Application in Housing}

Technology application in housing is the deployment of appropriate modern technologies and innovations for sustainable and affordable housing projects. Examples of modern building technologies 
include industrial building systems (IBS), which will ensure the completion of housing projects on a large scale, on time, on budget and attaining quality standards; thus, reducing maintenance costs. Governments should support the promotion of advanced construction technology and innovations in the building industry. Because buildings have several components put together by a variety of professionals and artisans, it becomes rife with disputes, delays, and material waste. Hence, the construction industry needs to adopt new and modern construction techniques and technology to be sustainable. More so, it will promote and boost employment by strengthening associated smalland medium-scaled and consulting enterprises. Some of these technologies include modular systems and 3D printing. Application of smart technology (BIM, big data, artificial intelligence) will help in enhancing design precision and professional collaboration in managing human, capital, and material resources throughout the life cycle of a building, and hence promote effective construction project management and maintenance cost reduction.

\subsection{Community Participation}

Community participation in housing development is promoting stakeholder participation and collaboration in the housing development process and equity in housing distribution, social amenities to all genders, the disabled, and the less privileged of society. Stakeholders in housing markets need to get involved in discussions and negotiations to make practical decisions regarding their housing needs. There should be in place a housing distribution system that is unbiased and equitable. A secure public investment management system should be established to encourage transparency and accountability; the government should put in place strong institutions that will promote good governance and robust implementation strategies that will check corruption and sharp practices. Additionally, housing provision should fulfill the provision of social amenities for the disadvantaged in society. To support this claim, Olotuah, in their study on Nigeria, posited that good governance and citizen participation are sacrosanct for any reasonable government embarking on a successful sustainable and affordable housing program. To succeed in initiating and implementing sustainable and affordable housing for low-income households, stakeholder participation in the decision-making process must be ensured [5]. A recent study in the UK conducted by Mulliner and Maliene, and Oyebanji A. propounded the need for community integration that can be sustainable over time. Similarly, in the UK, another study on sustainable social housing agreed on promoting social cohesion in housing development for low-income households [42,43].

\subsection{Affordability in Housing}

The document analysis on the economic success criteria in Figure 2 shows that House price concerning income ranks on top, while Rental costs concerning income and Interest rates and mortgage availability both rank second on the list. The other criteria having equal rankings include Housing Subsidy and Adequate Funding. Affordability is ranked seventh on the list of success criteria by the household (Figure 4). It involves the government giving incentives to cut down housing costs for low and middle-income earners through adequate funding, subsidies, and reduction of interest rates and mortgage financing for housing providers. The government has the responsibility to intervene in terms of providing incentives for housing providers to be actively involved in sustainable and affordable housing projects, such as providing land at affordable rates to estate developers. Additionally, the government should make adequate budget funding for housing schemes and programs and housing subsidies to low-income earners. To avoid a housing price bubble and bust, new sustainable real estate valuation parameters should be developed; for example, the econometrics of location, the price of land, and the cost of developing green buildings [44].

Furthermore Zou G. and Chau K. suggested that sustainable pricing is maintaining a stable housing price in the long run by introducing policies that will reduce inflation rate in the future; thus, the determining criteria to be investigated are housing sales, housing prices, housing completion and inflation rates [45]. According to Lorenz D. and Lützkendorf T., housing property valuations should 
include sustainability criteria or parameters to enable better pricing and appropriate estimations of buildings. The study further emphasized changing behavioral patterns of the household, which will, in turn, reflect the value of the property [46]. However, to appraise for pricing a large number of housing units, some criteria need to be considered, such as the characteristics of building fabrics and also the neighborhood [47].

\subsection{Acceptability of Housing}

Acceptability of housing is ensuring that building typologies reflect the cultures and lifestyles of people, which will be aesthetically and satisfactorily acceptable to the end-users. Building typologies are buildings types that are categorized according to class, type, and function. Cultural features are buildings that should reflect cultural values for their users. Lifestyle: due to the advent of advanced information technology, people spend more time indoors than having outdoor activities. Aesthetics: buildings are expected to be aesthetically designed and appealing to the eyes. Satisfaction: the building should help residents achieve happiness and satisfaction in nurturing a family. Moreover, other criteria to be looked into is housing satisfaction, which has been less studied. It was revealed in a study by Eziyi O. I. et al. in Nigeria that residents are dissatisfied with their residential facilities; hence, the housing is not acceptable [48]. The sustainable and affordable housing framework should not only cover economic aspects but also border on social issues, which include social amenities and housing quality, social status, and lifestyle [18-49]. Additionally, Pullen S. et al. propounded that housing should be socially adaptable by ensuring that there are appropriate density and dwelling size for a decent habitation [50].

Furthermore, studies have shown that there is a need to enhance the quality of residential welfare and livelihood to achieve economic, social and environmental viability in housing development through effective and efficient estate and project management of housing facilities [51]. Additionally, more government spending should be encouraged to supply more housing and incorporate other supporting social amenities to encourage social activities [3]. However, Yua Li et al. [52] argued that sustainable housing should depict community participation at the construction stages through effective communication and cooperation by the project participants, as supported by Mulliner and Maliene [53]. In research conducted in Lagos, Olatunji A. [54] stipulated that social and political interference in developing a sustainable housing model can be overcome through stakeholder participation and community involvement.

\section{Conclusions}

The study, therefore, derived, evaluated, and ranked sustainable and affordable housing success criteria, namely, security, accessibility, adaptability, utility, technology, community, affordability, and acceptability. Household findings reveal that security was favored over other criteria; this could be considered as an expression of growing concerns over and around the security of property and residential living. We find that adherence to environmental protection standards can be greatly improved with the efficient use and management of essential housing utilities such as energy and water.

The study recommends that there should be future research focused on the social and environmental dimensions of sustainable housing as it affects the household, especially in developing countries. More so, the study also recommends further research work on sustainable and affordable housing that delves solely on implementation strategies of other climes and also improves the model using more advanced and sophisticated analytical tools. The results derived from this study are limited and restricted to location, time, and data; thus, the method employed cannot be apply to other climes and periods.

Author Contributions: A.I.S. wrote the manuscript; A.I.S. and C.Y. provided relevant information, discussed the data, and corrected the manuscript; and C.Y. revised the manuscript. All authors have read and approved the final manuscript.

Funding: This research received no external funding. 
Conflicts of Interest: The authors declare no conflict of interest.

\section{Appendix A Questionnaire Survey for Households}

Questionnaire survey instructions:

From your perspective, how would you rank the Economic criteria for practically realizing housing development that is sustainable and affordable? Please rank between 1 (very low) to 5 (very high) with each of the following.

1. What is your Position and grade level in your ministry?

2. What is your gender?

3. What is Your Monthly income/wage?

4. How much is your Monthly Housing rent/mortgage/expenditure?

5. Do you own a House?

6. If Yes, how did you acquire the house?

Table A1. ECONOMIC PERSPECTIVE.

\begin{tabular}{|c|c|c|c|c|c|c|}
\hline No. & Question & \multicolumn{5}{|c|}{ Ranking (Tick as Appropriate) } \\
\hline 1 & $\begin{array}{l}\text { Provision of government incentives to cut down Housing } \\
\text { cost for low and middle-income earners through } \\
\text { adequate funding, subsidies and reduction of interest } \\
\text { rates and mortgage financing for housing providers. }\end{array}$ & 1 & 2 & 3 & 4 & 5 \\
\hline 2 & $\begin{array}{l}\text { Provision of quality and serviceable transportation } \\
\text { infrastructure (i.e., Bus service, road network, cycling } \\
\text { tracks and pedestrian side walk) in housing } \\
\text { projects/estates and also allows for easy and quick access } \\
\text { to and from place of employment and job opportunities. }\end{array}$ & & & & & \\
\hline 3 & $\begin{array}{l}\text { Deployment of appropriate modern technologies and } \\
\text { innovations for a sustainable and affordable housing } \\
\text { project. Examples of modern building technologies } \\
\text { include Industrial Building systems IBS, which will } \\
\text { ensure completion of housing in a large scale, on time, on } \\
\text { budget and attain quality standards; thus, reducing } \\
\text { maintenance cost. }\end{array}$ & & & & & \\
\hline
\end{tabular}

Table A2. SOCIAL PERSPECTIVE.

\begin{tabular}{|c|c|c|c|c|c|c|}
\hline No. & Question & \multicolumn{4}{|c|}{ Ranking (Tick as Appropriate) } & \\
\hline 1 & $\begin{array}{l}\text { Ensuring that building typologies reflect the cultures and } \\
\text { lifestyles of people, which will be aesthetically and } \\
\text { satisfactorily acceptable to the end users. }\end{array}$ & 1 & 2 & 3 & 4 & 5 \\
\hline 2 & $\begin{array}{l}\text { Promoting Stakeholder participation in housing } \\
\text { development process and equitable access to housing } \\
\text { units and social amenities to all gender, disabled and the } \\
\text { less privileged of the society. }\end{array}$ & & & & & \\
\hline 3 & $\begin{array}{l}\text { Ensuring comfortability by providing effective } \\
\text { estate/facilities management practice to maintain the } \\
\text { quality and value of housing assets. Furthermore, } \\
\text { ensuring security of lives and property of the end users. }\end{array}$ & & & & & \\
\hline
\end{tabular}


Table A3. ENVIRONMENT PERSPECTIVE.

\begin{tabular}{llll}
\hline No. & \multicolumn{1}{c}{ Question } & Ranking (Tick as Appropriate) \\
\hline 1 & $\begin{array}{l}\text { Enforcing environmental protection standards to control } \\
\text { air, water and noise pollution during and after } \\
\text { construction of housing projects by reducing, reusing and } \\
\text { recycling construction material waste and also using } \\
\text { locally available building materials. }\end{array}$ & 1 & 2 \\
\hline & $\begin{array}{l}\text { Promoting and ensuring efficient use of energy and water } \\
\text { in the building, by the use of alternative renewable } \\
\text { sources of generating energy and installation of electrical } \\
\text { and plumbing controls to reduce the life cycle cost of } \\
\text { buildings. }\end{array}$ \\
\hline
\end{tabular}

Thank you for taking the time to complete the questionnaire!

\section{References}

1. The World Bank Annual Report 2018. Available online: http://documents.worldbank.org/curated/en/ 630671538158537244/The-World-Bank-Annual-Report-2018 (accessed on 9 November 2019).

2. Living and Leaving: Housing Mobility and Welfare in the European Union. Available online: https: //elibrary.worldbank.org/doi/abs/10.1596/30898 (accessed on 9 November 2019).

3. Arnab, J.; Ronita, B.; Sayantani, S.; Vaibhav, K. Framework to Assess and Locate Affordable and Accessible Housing for Developing Nations: Empirical Evidences from Mumbai. Habitat Int. 2016, 57, 88-99.

4. Han, C.O.; Dennis, L. Partnerships between Stakeholders in the Provision of and Access to Affordable Housing in Malaysia. In Proceedings of the FIG XXII International Congress, Washington, DC, USA, 19-26 April 2002.

5. Olotuah, A.O.; Bobadoye, S.A. Sustainable and affordable housing Provision for the Urban Poor: A Review of Public Sector. Built Hum. Environ. Rev. 2009, 2, 51-63.

6. Olotuah, A.O.; Aiyetan, A.O. Sustainable Low-cost Housing Provision in Nigeria: A Bottom-Up Participatory Approach. In Proceedings of the 22nd Annual ARCOM Conference, Birmingham, UK, 4-6 September 2006; Association of Researchers in Construction Management: Birmingham, UK, 2006; pp. 633-639.

7. Jiboye, A.D. Achieving Sustainable and affordable housing development in Nigeria: A Critical Challenge to Governance. Int. J. Humanit. Soc. Sci. 2011, 1, 121-127.

8. Pat-Mbano, E.; Nwadiaro, E. The Rise of Urban Slum in Nigeria: Implications on the Urban Landscape. Int. J. Dev. Manag. Rev. 2012, 7, 1.

9. Trading Economics: Nigeria Living Wage. Available online: https://tradingeconomics.com/nigeria/livingwage-individual (accessed on 11 December 2019).

10. Aminu, B. Review of the Housing Policies and Programmes in Nigeria. Int. J. Contemp. Res. Rev. 2019, 10, 20603-20616.

11. Aminu, G.W.; Ruhizal, R. Housing Policies and Programmes in Nigeria: A Review of the Concept and Implementation. Bus. Manag. Dyn. 2013, 3, 60-68.

12. Eziyi, O.I.; Dominic, E.A. Framework for Evaluating the Sustainability of Public Housing Prorammes in Developing Countries. J. Sustain. Dev. Environ. Prot. 2011, 1, 24-39.

13. Paulinus, W.I.; David, E. A Framework for the Sustainable Management of Social (Public) Housing Estates in Nigeria: A Pilot Study. In Proceedings of the Construction, Building and Real Estate Research Conference; Royal Institution of Chartered Surveyors: Manchester, UK, 2013.

14. Paulinus, W.I.; Iyenemi, I.K.; David, E. A review of Critical Project Management Success Factors (CPMSF) for sustainable social housing in Nigeria. Int. J. Sustain. Built Environ. 2014, 3, 62-71.

15. Fakunle, A.; Ogundare, J.; Olayinka-Alli, L.; Aridegbe, M.; Bello, T.; Elujulo, O. Housing quality and risk factors associated with respiratory health conditions in Nigeria. In Housing; Almusaed, A., Almssad, A., Eds.; IntechOpen: London, UK, 2018; pp. 19-20.

16. UN-HABITAT. Cities and Climate Change: Global Report on Human Settlements; UN-Habitat: Nairobi, Kenya, 2011; pp. $1-71$. 
17. IPCC. Global Warming of $1.5^{\circ}$ C. Summary for Policy Makers; IPCC: Geneva, Switzerland, 2018; pp. 6-11.

18. United Nations. Sustainable Development Goals; Knowledge Platform. Available online: https: //sustainabledevelopment.un.org/?menu=1300 (accessed on 19 November 2019).

19. Salama, A.M. A Life Style Theories Approach for Affordable Housing Research in Saudi Arabia. Emir. J. Eng. Res. 2006, 11, 67-76.

20. Albert, P.C.; Micheal, A. Bridging the Gap between Sustainable and affordable housing and Affordable Housing: The Required Critical Success Criteria (CSC). Build. Environ. 2019, 151, 112-125.

21. Mohammad, S.S.; Keisuke, K.; Ahmad, J.H.; Mohammad, K.H.; Daishi, S. Investigation of Sustainable and Affordable Housing Policy Principle and Formulation Adoptable in Kabul City, Afghanistan. J. Sustain. Dev. 2016, 9, 93. [CrossRef]

22. UN-HABITAT. Sustainable and Affordable Housing for Sustainable Cities: A Policy Framework for Developing Countries; UN-HABITAT: Nairobi, Kenya, 2012; pp. 17-73.

23. Mitlin, D.; Satterthwaite, D. Sustainable Development and Cities; Pugh, C., Ed.; Earthscan Publication Limited: London, UK, 1996; pp. 23-62.

24. Glenn, A.B. Document Analysis as a Qualitative Research Method. Qual. Res. J. 2009, 9, 27-40.

25. Blaikie, N.W.H. Designing Social Research: The Logic of Anticipation, 3rd ed.; John Wiley \& Sons: Hoboken, NJ, USA, 2019.

26. Akintoye, A.; McIntosh, G.; Fitzgerald, E. A survey of supply chain collaboration and management in the UK construction industry. Eur. J. Purch. Supply Manag. 2000, 6, 159-168. [CrossRef]

27. Surveygizmo. Survey Response Rate. In Best Practices; Donna, Ed.; Surveygizmo: Boulder, CO, USA, 2010; Available online: http://www.surveygizmo.com/survey-blog/survey-response-rates/ (accessed on 12 December 2019).

28. Emsley, S.; Peter, P.; Louise, C. Models of Sustainable and Affordable Housing for Local Government: Final Report; Urban Research Centre, University of Western Sydney: Sydney, Australia, 2008; pp. 20-27.

29. Ashraf, M.S.; Habib, M.A. A Trans-Disciplinary Approach for a Comprehensive Understanding of Sustainable Affordable Housing. Glob. Built Environ. Rev. 2006, 5, 35-50.

30. Xiaosen, H.; Ann, T.W.; Amos, D.; Zezhou, W. Critical factors in site planning and design of green buildings: A case of China. J. Clean. Prod. 2019, 222, 685-694.

31. Caleb, A.A.; Samuel, A.O.; Adedamola, O.O.; Omolade, A.A. The Role of Education towards Achieving Sustaining Housing and Environmental Development in Nigeria. Covenant J. Res. Built Environ. 2018, 6, 65-73.

32. Muhamad, F.M.; Mohammad, F.M.; Rohana, M.; Mohd, R.Y. Enhancing the Quality of Life by Adopting Sustainable Modulised Building System (IBS) in the Malaysian Construction Industry. Procedia Soc. Behav. Sci. 2014, 153, 79-89.

33. Gbadegesin, J.T.; Van Der, H.; Heijden, P.B. Land Accessibility Factors in Urban Housing Provision in Nigerian Cities: Case of Lagos. In Proceedings of the European Network for Housing Research Conference, Belfast, Northern Ireland, 28 June 2016; p. 9.

34. Rosli, S.; Rohayu, A.; Majid, A.A.; Yasmin, M.A.; Muhammad, N.R. Sustainable and affordable housing in Sabah. J. Malays. Inst. Plan. 2016, 14, 65-76.

35. Omar, S.A. The role of Land Planning Policies in Supporting Housing Affordability: The Case of the Gaza Strip. Land Use Policy 2016, 62, 40-48.

36. Afolabi, A. Housing Affordability as a Factor in the Creation of Sustainable Environment in Development World: The example of Akure, Nigeria. J. Hum. Ecol. 2011, 35, 121-131.

37. Carolyn, S.H. An Examination of the Relationship between Sustainability and Affordability in Residential Housing Markets. Available online: https://pdfs.semanticscholar.org (accessed on 21 October 2019).

38. Kamand, M.R.; Abu Hassan, A.; Amin, A.T. Energy-efficient design for sustainable housing development. J. Clean. Prod. 2014, 65, 380-388.

39. Li, C.; Yeonjin, B.W.; Travis, H. A system-level approach for designing multi-family sustainable and energy efficient housing communities. Sustain. Cities Soc. 2019, 44, 183-194.

40. Héctor, S.; José, M.; Susana, P.A.; Diana, C.G.; Ramón, C. Sustainable social housing: The comparison of the Mexican funding program for housing solutions and building sustainability rating systems. Build. Environ. 2017, 133, 103-122. 
41. Mohammad, K.; Kasun, H. Life cycle performance of modular buildings: A critical review. Renew. Susstain. Energy Rev. 2016, 62, 1171-1183.

42. Mulliner, E.; Smallbone, K.; Maliene, V. An Assessment of Sustainable and affordable housing using a Multiple Criteria Decision-Making Method. Omega-Int. J. Manag. Sci. 2012, 41, 270-279. [CrossRef]

43. Oyebanji, A.O. Development of a Framework for Sustainable Social Housing Provision (SSHP) in England. Ph.D. Thesis, University of Central Lancashire, Preston, UK, 2014.

44. Krause, A.L.; Bitter, C. Spatial econometrics, land values and sustainability: Trends in real estate valuation research. Cities 2012, 29, S19-S25. [CrossRef]

45. Zou, G.; Chau, K. Determinants and sustainability of house prices: The case of Shanghai, China. Sustainability 2015, 7, 4524-4548. [CrossRef]

46. Lorenz, D.; Lützkendorf, T. Sustainability in property valuation: Theory and practice. J. Prop. Invest. Financ. 2008, 26, 482-521. [CrossRef]

47. Arribas, I.; García, F.; Guijarro, F.; Oliver, J.; Tamošiūnienè, R. Mass appraisal of residential real estate using multilevel modelling. Int. J. Strateg. Prop. Manag. 2016, 20, 77-87. [CrossRef]

48. Eziyi, O.I.; Emmanuel, A.A.; Adedamola, O.O.; Oluwole, A.A. Residential Satisfaction among Low-income earners in Government-Subsidized Housing Estate in Ogun State, Nigeria. Urban Forum 2018, 30, 75-96.

49. Emma, M.; Naglis, M.; Vida, M. Comparative analysis of MCDM methods for the assessment of sustainable and affordable housing. Omega 2015, 59, 146-156.

50. Pullen, S.; Zillante, G.; Arman, M.; Wilson, L.; Zuo, J.; Chileshe, N. A case study analysis of sustainable and affordable housing. In Proceedings of the 35th Annual Conference Australasian Universities Building Education Association, Melbourne, Australia, 14-16 July 2010; pp. 1-18.

51. Mulliner, E.; Maliene, V. An Analysis of Professional Perceptions of Criteria Contributing to Sustainable and affordable housing. Sustainability 2014, 7, 248-270. [CrossRef]

52. Li, Y.; Song, H.; Sang, P.; Chen, P.H.; Liu, X. Review of Critical Success Factors (CSFs) for green building projects. Build. Environ. 2019, 158, 182-191. [CrossRef]

53. Emma, M.; Vida, M. Criteria for Sustainable and affordable housing. In Proceedings of the the 8th International Conference on Environmental Engineering, Vilnius, Lithuania, 19-20 May 2011; Vilnius Gediminas Technical University Press: Technika, Lithuania, 2011.

54. Olatunji, A.O. The Development of a Framework for Sustainable Housing Delivery in Lagos, Nigeria. Ph.D. Thesis, University of Wolverhampton, Wolverhampton, UK, 2014. 